\title{
Feldstein-Horioka Hipotezinin AB-15 ve Türkiye Ekonomisi için Sınanması: Yatay Kesit Bağımlılığı Altında Yapısal Kırılmalı Dinamik Panel Veri Analizi
}

\author{
The Testing Feldstein-Horioka Hypothesis For EU-15 and Turkey: Structural Break \\ Dynamic Panel Data Analysis Under Cross Section Dependency
}

Mehmet MERCAN ${ }^{1}$

\begin{abstract}
ÖZET
Yatırım ve tasarruflar ülkelerin sürdürülebilir ekonomik büyümeyi sağlayabilmelerinde önemli makroekonomik belirleyicilerdir. Yatırım-tasarruf ilişkisi birçok çalışmaya konu olmakla birlikte Feldstein-Horioka (1980), yatırım-tasarruf ilişkisini uluslararası sermaye hareketliliği ile izah etmektedir. Sermaye hareketleri üzerinde kısıtlamaların olduğu durumda, yatırımların yurt içi tasarruflarla finanse edileceğini ve yatırımtasarruf ilişkisinin güçlü olacağını, aksi takdirde ilişkinin olmayacağını ya da düşük düzeyde olacağı savını öne sürmektedir.

Bu çalışmada; Feldstein-Horioka (F-H) hipotezi, AB ülkeleri ve Türkiye Ekonomisi örneğinde yapısal kırılmaları dikkate alan yeni nesil dinamik panel veri analizi ile sınanmıştır. Analizde, herhangi bir ülkede meydana gelen bir makroekonomik şokun diğer ülkeleri de etkileyeceği varsayımını yani yatay kesit bağımlıı̆ı̆ı dikkate alan birim kök ve eş-bütünleşme testleri uygulanmıştır. Analiz sonucunda ülkelerin geneli için yatırım-tasarruf serileri arasında zayıf eş-bütünleşme ilişkisi elde edilmiş ve bu ülkelerde $\mathrm{F}-\mathrm{H}$ hipotezinin geçerli olduğu bulgusu elde edilmiştir. Kısa dönem analizinde ise tasarrufların yatııımları karşılama düzeyinin daha düşük olduğu görülmüştür.
\end{abstract}

Anahtar Kelimeler: Feldstein-Horioka hipotezi, tasarruf oranları, yatırımlar, sermaye hareketleri, yatay kesit bağımlıı̆ı.

\section{GíRiş}

Ülke ekonomileri için yatırımlar ve tasarruflar sürdürülebilir ekonomik büyümenin en önemli belirleyicilerindendir. Özel sektör ya da kamu tarafından yapılan yatırımlar uzun dönemde ekonomik büyüme, cari açık, işsizlik gibi ekonomik ve sosyal birçok sorunun çözümünü kolaylaştıracaktır. Tasarruf ise yatırımlar için gerekli finansmanı sağlayarak büyümenin sürdürülebilirliğini mümkün kılacaktır. Yurt içi tasarrufların olmadığı durumda ise gerekli kaynak uluslararası piyasalardan sağlanmak zorundadır. Yurt içi tasarrufların yurt içi yatırımları finanse edememesinin sonucu olarak, uluslararası sermaye akımlarında artışlar mey-

\begin{abstract}
Investments and savings are significant macroeconomic determiners for countries to maintain their sustainable economic growth. Although investment-saving relationship is subject to many studies, Feldstein-Horioka (1980) explain the investment-saving relationship with international capital mobility. They suggest that investments will be financed with domestic savings and investment-saving relationship will be strong, otherwise there will be no relationship or the relationship will be in the low level in the case of restrictions on capital movements.

In this study Feldstein-Horioka (F-H) hypothesis was tested with the new generation dynamic panel data analysis considering the structural breaks in EU-15 countries and Turkey. Unit root and cointegration tests considering the hypothesis that a macroeconomic shock in a country would affect the other countries, in other words the cross sectional dependency were implemented in this analysis. As a result of the analysis, for the countries overall a weak cointegration relationship between investment-saving series was obtained and it was found that $\mathrm{F}-\mathrm{H}$ hypothesis is valid for these countries. However, it was found that the level of savings to meet investments was lower in the short term analysis.
\end{abstract}

Keywords: Feldstein-Horioka hypothesis, saving rate, investment, capital movement, cross section dependency.

dana gelmektedir (Brezis, 1995:56). Fakat son yıllarda uluslararası fonların sürekliliğinin tartışılması, gelen fonların reel ekonomiden bağımsız olarak kısa dönemli kar amaçlı alım-satım işlemlerinden oluşması ve spekülatif amaçı portföy yatırımlarına yönelmesi, yatırım-tasarruflar sorunsalını tekrar gündeme getirmiştir. Nitekim Bhagwhati (1998), Stiglitz (2002) ve Rodrik (1998) finansal açıklığın büyümeyi arttırmadığını hatta krizlere yol açabileceğini belirtmiştir. Ayrıca, ülkelerin küresel ekonomiye entegrasyonunun artması ile birlikte, uluslararası sermaye girişlerinin arttığı ve sonuç olarak yabancı tasarrufların yurt içi tasarrufları dışladığını belirtmiştir (Boratav, 2009). 
Literatürde yatırım-tasarruf ilişkisi birçok çalışmada farklı yöntemlerle test edilmiştir. Feldstein-Horioka (1980)'nın yatırım-tasarruf iliş̧kisini incelediği çalışması köşe taşı niteliğindedir. Feldstein ve Horioka (1980) çalışmasında, 1960-1974 dönemi için 16 sanayileşmiş OECD ülkesi örneğinde Solow modelinin ${ }^{1}$ uluslararası sermaye hareketliliği ile ilgili hipotezlerini dolaylı olarak takip ederek, incelenen ülke ekonomilerindeki sermaye hareketliliğinin düzeyini yatırım-tasarruf ilişkisini analiz ederek incelemiş ve ilişkiyi yüksek bulmuştur (Mangır ve Ertuğrul, 2012). İncelenen dönemde sermaye piyasalarının gelişmiş olmaması ve küreselleşme ve deregülasyonların 1970'lerden itibaren arttığı dikkate alınırsa çalışmanın sonucu sermaye hareketliliğinin düşük olduğu şeklinde yorumlanmıştır. Fakat sonraki dönemde yapılan çalışmalarda da (Feldstein, (1983), Feldstein ve Bachetta (1991)) ilişkinin yüksek çıkması ile bu olgu Feldstein-Horioka paradoksu olarak ta adlandırılmış ve bu durumun nedenleri araştırılmıştır.

Feldstein-Horioka paradoksunun nedeni olarak; Tesar (1991), hayat döngüsü (life-cycle) hipotezini öne sürmüş, tasarruflar ve büyümenin doğrusal ilişkili olduğunu ve doğal olarak yatırım-tasarruf ilişkisinin yüksek olacağını belirtmiştir. Bazı çalışmalar ise; cari açık sorunu olan ekonomi yönetimlerinin cari açığı finansmanı için sermaye hareketlerine izin verdiği dolayısıyla yatırım-tasarruf ilişkisinin sermaye hareketlerinden bağımsız olduğu ifade etmektedir (Sachs, 1981; Tobin, 1983; Coakley ve Kulasi 1997). Benzer şekilde Jansen (1998) ise, bütçe açığının finansmanının dış fonlarla sağlanması durumunda yatırım-tasarruf ilişkisinin sermaye hareketleriyle ilgisinin olmadığını belirtmiştir. Murphy (1984) ve Mamingi (1993), yatırım-tasarruf ilişkisi hesaplanırken ülkenin büyük ülke olmasının oldukça önemli olduğunu belirtmiştir. Çünkü ülke büyüklüğü dünya faiz oranını etkileyebilecek düzeyde ise, yurt içi tasarruflarının artması dünya faiz oranını düşürecek ve böylece yurt içi yatırımlar artacaktır. Yani yatırım-tasarruf ilişkisi büyük ülkelerde yüksek, küçük ülkelerde ise az olacaktır. Georgopoulos ve Hejazi (2005) ise yatırım-tasarruf ilişkisinin yüksek olmasını ülkedeki yatırımcıların fonlarını, yurt dışı araçlarda getirisi daha yüksek olsa bile farklı nedenlerle (işlem maliyetleri vb.) yurt içi araçlarda değerlendirme eğiliminde olmasına bağlamıştır. Bu durum "hisse ev tercihi paradoksu (equity home bias paradox)" olarak adlandırılmaktadır (French ve Poterba (1991); Tesar ve Werner (1995)) ve örnek olarak dünyanın en büyük beş borsasında yurt içi yatırımların payı; Amerika'da \%92.2, Japonya'da \%95.7, İngiltere'de \%92, Almanya'da \%79 ve Fransa'da \%89.4'tür (French ve Poterba; 1991).
Bu çalışmanın amacı, Feldstein-Horioka hipotezinin geçerliliğini $A B-15$ ülkeleri ve Türkiye açısından geçerliliğini sınamaktır. Çalışmada incelenen ülkeler aynı entegrasyonda olduğundan (Türkiye hariç) herhangi bir ülkede meydana gelen makroekonomik şok diğerlerini de etkileyecektir. Bu bağlamda yapılan analizde bu varsayımı (yatay kesit bağımlıığını) ve birim kök ve eşbütünleşme analizlerinde yapısal kırılmaları dikkate alan yeni nesil panel birim kök, panel eşbütünleşme, uzun ve kısa dönem analizleri yapılmıştır. Feldstein-Horioka hipotezinin geçerliliği çerçevesinde Türkiye örneğinde yapılan çalışmalar oldukça sınırlıdır, ayrıca AB-15 ülkeleri ve Türkiye'nin ele alındığı çalışma yoktur. Çalışmanı $A B-15$ ve Türkiye örneğinde olması, yatay kesit bağımlılığını ve serilerde ve eşbütünleşme denkleminde yapısal kırılmaları dikkate alan yeni nesil panel veri analizlerinin kullanılması çalışmayı farklılaştırmaktadır ve bu yönüyle literatüre katkı yapacağı düşünülmektedir.

Çalışmanın giriş kısmını takip eden bölümde, literatürdeki teorik ve ampirik çalışmalara yer verilmiş, üçüncü ölümde uygulanacak metodoloji anlatılmıştır. Dördüncü bölümde analiz ve ampirik bulgular yorumlanmıştır. Son bölümde ise, çalışmanın genel değerlendirilmesi ve politika önerileri sunulmuştur.

\section{LITERATÜR TARAMASI}

Literatürde sermaye hareketliliği ile yatırım-tasarruf ilişkisi Feldstein ve Horioka (1980) çalışmasını takiben birçok çalışmaya konu olmuştur. Küreselleşme süreci ile birlikte sermaye hareketliliğinde meydana gelen artışlar sonucu F-H hipotezi sıklıkla test edilmektedir (Bolatoğlu, 2005: 20). Bu hipotezi sınayan ampirik çalışmalar tarih sırasına göre bu bölümde verilmiştir.

Feldstein (1983), F-H hipotezini 1974-1979 dönemi verileri ile analize net dış yatırımlar-yurt içi yatırımlar arasındaki ilişkiyi de eklemiştir. Çalışmada incelenen 17 ülke için, yurt içi tasarruflar-yatırımlar arasındaki ilişkinin güçlü olduğu bulgusunu elde etmiştir. Bu çalışma sonuçları Feldstein-Horioka (1980) çalışmasına paralellik arz etmektedir.

Penati ve Dooley (1984), 19 ülke örneğinde F-H hipotezini sermaye hareketlerinin olduğu ve olmadığı farklı dönemleri kullanarak test etmiştir. Analiz sonuçları F-H hipotezi ile uyumlu olarak, yatırım-tasarruf arasında güçlü bir ilişki elde etmişlerdir.

Murphy (1984), 17 OECD ülkesi için yaptığı analizde yedi gelişmiş ülke için $\beta=0.98$ katsayısının, on gelişmekte olan ülkedeki $\beta=0.59$ katsayısından daha büyük olduğu bulgusunu elde etmiştir. Bu sonuçlar F-H hipotezi ile uyumlu değildir. 
Caprio ve Howard'ın (1984), 23 OECD ülkesi örneğinde, 1963-1981 dönemi için yaptıkları analizde yatırım-tasarruf ilişkisinin zayıf olduğu bulgusunu elde etmişlerdir. Bu bulgu, F-H hipotezi ile uyumlu değildir.

Obstfeld ve Rogoff (1996), 22 OECD ülkesi için sermaye hareketliliğinin tam olmadığı 1982-1991 dönemi verileriyle analiz etmiş ve $\beta$ katsayısını 0.62 bulmuştur. Analiz sonucunun F-H hipotezini desteklediğini belirtmiş̧tir.

Apergis ve Tsoulfidis (1997), 14 AB ülkesi örneğinde yatırım-tasarruf ilişkisini incelemiş, analizde yatırımları temsilen kredileri kullanmıştır. Analiz sonucunda sermaye hareketliliği derecesinin yatırımları önemli düzeyde etkilemediğini, yatırımların en fazla yurt içi tasarruflardan etkilendiğini belirtmiş̧ir.

Kim (2001), çalışmasında 19 OECD ülkesi örneğinde 1960-1992 dönemi verileri ile yaptığı analizde Feldstein ve Horioka'nın sonuçlarını doğrulamış ve yatırım-tasarruf ilişkisini yüksek bulmuştur.

Blanchard ve Giavazzi (2002), yatırım-tasarruf ilişkisini, 1975-2001 dönemi için OECD ülkeleri örneğinde ve 1991-2001 dönemi için Euro bölgesi örneğinde incelemişler ve ilişkinin hem OECD ülkeleri hem de Euro bölgesi için başlangıçta güçlü olmakla birlikte zaman içinde azaldığını tespit etmiştir. Euro bölgesi için ilişkinin düşük olmasının nedeni olarak F-H hipotezine paralel olarak ülkelerin entegrasyonu ve sermaye hareketliliğinin yüksek olmasını belirtmişlerdir.

Helliwell (2004) ve Amirkhalkhali vd. (2003), OECD ülkeleri örneğinde 1971-1999 dönemi için yaptığı analizde yatırım-tasarruf ilişkisinin olduğunu fakat ilişkinin zaman içerisinde zayıfladığını ifade etmişlerdir.

Abbott ve De Vita (2003), İngiltere örneğinde 1955:1-1999:4 dönemi çeyrek verilerini kullanarak, sınır testi ile yaptıkları analizde, Feldstein-Horioka hipotezini doğrulayan sonuçlar elde etmişlerdir. Ingiltere örneğinde yapılan bir diğer çalışma Özmen ve Parmaksız (2003) çalışmasıdır. Yazarlar, F-H hipotezinin İngiltere örneğinde 1948-1998 döneminde incelemiş ve 1979 'dan itibaren sermaye hesabı liberalizasyonu sonrası yatırım-tasarruf ilişkisinin azaldığını vurgulamıştır.

Narayan (2005) 1952-1998 Çin örneğinde yaptığı çalışmasında sermaye hareketlerinin kısıtlı olduğu dönemde yatıım-tasarruf ilişkisinin varlığına işaret etmiştir. Bulguları F-H hipotezini destekler niteliktedir.

Baxter ve Crucini (1993), yaptığı teorik çalışmasında F-H hipotezinden farklı olarak sermaye hareketliliği üzerinde kısıtların olmadığı durumda da yatırım- tasarruf ilişkisinin yüksek olabileceğini ifade etmiştir.

Feldstein ve Bacchetta (1989) ve Tesar (1991) 23 OECD ülkesi örneğinde 1960-1986 dönemi verileriyle yatırım-tasarruf ilişkisini incelemiştir. Tesar (1991) analizinde net tasarruf ve yatırım oranlarını kullanmıştır. Yazarlar çalışmalarında kısa ve uzun dönemde güçlü ilişki elde etmişlerdir.

Hussein (1998), 23 OECD ülkesi için 1960-1993 ve 1970-1993 dönemleri olmak üzere yaptığı iki farklı analizde, incelenen ülkelerin 18 'inde F-H hipotezinin geçerli olmadığını, 5 ülkede ise hipotezin desteklendiğini ifade etmiştir.

Sinha ve Sinha (1998), 10 Latin Amerika ülkesi örneğinde yatırım-tasarruf ilişkisini Johansen-eşbütünleşme analiziyle incelemişlerdir. Analiz sonucunda sadece Ekvador, Honduras, Jamaika ve Panama olmak üzere sadece dört ülkede uzun dönemde güçlü ilişki olduğunu bulmuşlardır.

Rocha ve Zerbini (2003) yatırım-tasarruf ilişkisini 29 gelişmekte olan ülkenin 1960-1996 dönemi verileriyle incelemiş ve güçlü bir eşbütünleşme ilişkisi elde etmiştir. Fakat analiz sonucunu F-H hipotezini, yani sermaye hareketliliğinin derecesini değil uzun dönem borçların sürdürülebilirliğini test etmiştir.

Ang (2007) Malezya örneğinde sermaye liberalizasyonunun olduğu 1965-2003 dönemi için yaptığı analizde yatırım-tasarruf ilişkini elde etmişlerdir. Bu sonuç F-H hipotezi Malezya ekonomisi örneğinde doğrulamamaktadır.

Kollias vd. (2008) AB-15 ülkeleri için sınır testi ve panel veri analizi ile yaptığı çalışmada $\beta$ katsayısını 0.148 olarak bulmuştur. İlgili ülkelerde tam sermaye hareketliliği olduğu göz önüne alındığı zaman ilişkinin düşük olması F-H hipotezini desteklemektedir. Benzer sonucu Pelagidis ve Mastroyiannis (2003), Yunanistan için yapmış ve $\beta$ katsayısını 0.91 olarak elde etmiş̧ir.

Ketenci (2012), 23 AB üyesi ülke için 1995-2009 dönemi için yatırım-tasarruf ilişkisini F-H hipotezi çerçevesinde incelediği yapısal kırılmaları dikkate alan analizinde, Belçika hariç diğer ülkelerde hipotezin geçerli olmadığını belirtmiştir.

Literatürde Türkiye için yapılan bazı ampirik çaIışmalar ise şu şekildedir. Erden (2005) çalışmasında Türkiye Ekonomisi'nin 1963-2002 dönemi sermaye hareketlerinde kısıtların olduğu 1980 yılını baz alarak iki farklı dönemde incelemiştir. Analiz sonucunda, kısıtların olmadığı 1980 öncesi dönemde yatırım-tasarruf ilişkisi güçlü iken kısıtların kaldırıldığı 1980 sonrası dönemde ilişkinin zayıfladığı sonucuna ulaşmıştır. Analiz sonuçları F-H hipotezini doğrular niteliktedir. 
Bolatoğlu (2005) 1970-2003 dönemini kapsayan çalışmasında F-H hipotezini Engle-Granger Eşbütünleşme ve Sınır testi yaklaşımlarıyla incelemiştir. Engle-Granger eşbütünleşme analizinin bulgularının uygulanan birim kök testlerinde farklılık göstermesi nedeniyle Sınır testi analizyapmış ve analiz sonucunda, yatırım ve tasarruflar arasında eşbütünleşme ilişkisi tespit etmiş̧ir. Fakat eşbütünleşme ilişkisinin bire bir olmadığını ve bunun sebebi olarak Türkiye'nin büyük ülkeler kadar sermaye hareketliliği olmamasını gerekçe göstermiştir.

Altıntaş ve Taban (2011), 1974-2007 dönemi verileriyle Türkiye ekonomisinde ikiz açık ve F-H hipotezinin geçerliliğini incelemişlerdir. Analiz sonucunda, Türkiye için F-H hipotezinin geçerli olduğunu fakat ilişkinin düşük olduğunu yani yatırımların \%60'ının dış fonlarla finanse edildiğini belirtmiş ve bunun sebebi olarak Türkiye'nin dünya piyasalarına yeterinde entegre olamamasını göstermiştir.

Esen vd. (2012), 1975-2009 dönemi için F-H hipotezinin geçerliliğini Türkiye ekonomisinde incelemişlerdir. Analiz sonucunda, yatııım-tasarruf ilişkisinin zayıf olduğunu, sermaye hareketlerinin artmasına paralel olarak ilişkinin zayıfladığını belirtmiş ve Türkiye için F-H hipotezinin geçerli olduğunu ifade etmiştir.

Mangır ve Ertuğrul (2012), 1980 ve 2010 dönemi için yatırım tasarruf ilişkisini sınır testi ve Kalman filtreleme yaklaşımıyla incelemiştir. Çalışma sonucunda, yatırım-tasarruf serileri arasında eşbütünleşme ilişkisi olduğunu belirtmişlerdir. Kalman filtreleme yaklaşımına göre ise yıllara göre ilişkinin azaldığını ve F-H hipotezinin geçerli olduğunu belirtmiştir.

\section{MODEL VE YÖNTEM}

AB-15 ülkeleri ve Türkiye'de yatırım-tasarruf ilişkisini analiz etmek amacıyla çalışmada Feldstein ve Horioka (1980) çalışması takip edilmiştir. Yazarlar çalışmasında uluslararası sermaye hareketliliğinin düzeyini test etmek amacıyla yatırım-tasarruf ilişkisini kullanmışlardır. Feldstein-Horioka (F-H) hipotezi olarak bu olguya göre; yüksek düzeyde sermaye hareketliliğinin varlığı durumunda yurt içi yatıımlar dış fonlarla finanse edilecek ve ilgili ülkede yatırım-tasarruf ilişkisi düşük olacaktır, düşük düzeyde sermeye hareketliliğinin varlığı durumunda ise yatırım-tasarruf iliş̧kisinin yüksek olacağı savını öne sürmektedir (Esen, vd. 2012). Feldstein-Horioka (1980) yatırımlar ve tasarruflar arasındaki ilişkiyi incelediği çalışmasında ve çalışmamızda kullanılan regresyon denklemi şu şekildedir:

$$
(I / Y)_{t}=\alpha+\beta(S / Y)_{t}+u_{t}
$$

burada; $I, S$ ve $Y$ sırasıyla yurt içi toplam yatırım- ları, yurt içi toplam tasarrufları ve Gayri Safi Yurt içi Hasıla'yı göstermektedir. Literatürde $\beta$ "alıkonulan tasarrruf katsayısı (saving retention coeffıcient)" olarak adlandırılmaktadır (Bolatoğlu, 2005). Denklem (1)'de yer alan $\beta$ katsayısının tahmin değeri yatırım-tasarruf ilişkisinin düzeyini verecektir. Yatırım-tasarruf ilişkisi ne kadar zayıf ise, katsayı sıfıra yakın olacaktır. İlişki güçlendikçe katsayı 1'e yaklaşacaktır. Literatürde yapılan çalışmalarda sermayenin uluslararası hareketliliği çerçevesinde Feldstein-Horioka çalışmasının sonuçlarını netleştirememiştir. Ayrıca literatürde $\beta$ katsayısının sermaye hareketliliğinin düzeyinden ziyade cari işlemler açığının sürdürülebilirliğini test ettiği savını öne süren çalışmalarda vardır (Tesar (1991), Husted (1992), Coakley vd. (1996), Rocha and Zerbini (2003), Mercan ve Göçer (2012)). Bu çalışmalarda yatırım-tasarruf serilerinin eşbütünleşik ve katsayının bir olmasını sürdürülebilirliğin kanıtı olarak yorumlamışlardır. Literatürde yapılan çalışmalarda fikir birlikteliği olmasa da tüm çalışmalarda ortak nokta $\beta$ katsayısının anlamlılığı çerçevesinde şekillenmektedir.

Yatırım-tasarruf ilişkisini incelediğimiz çalışmamızda, seriler arasındaki eşbütünleşme ilişkisini incelemeden önce paneli oluşturan yatay kesitler (ülkeler) arasındaki bağımlıığın (YKB) olup olmadığı ilk kez Breusch-Pagan (1980) tarafından ortaya atılan (Lagrange Multiplier-LM testi) ve Pesaran vd. (2008) tarafından sapması düzeltilen $\mathrm{LM}_{\text {adj }}$ (Bias-Adjusted Crossectionally Dependence Lagrange Multiplier) testiyle incelenmiştir. Seriler için birim kök testi olarak; yatay kesit bağımlılığını ve serilerdeki yapısal kırılmalar dikkate alan ikinci kuşak birim kök testlerinden, Carrion-i Silvestre vd. (2005) tarafından geliştirilen PANKPSS (Panel Kwiatkowski-Phillips-Schmidt-Shin) testi kullanılmıştır. Eş-bütünleşme katsayılarının homojenliği, yani açıklayıcı değişkenin katsayılarının yatay kesitten (ülkeden) yatay kesite değişip değişmediği; Pesaran ve Yamagata (2008) tarafından geliştirilen Slope Homogeneity Testi'yle incelenmiştir. Seriler arasındaki eş-bütünleşme ilişkisinin varlığı; Basher ve Westerlund (2009) tarafından geliştirilen, yatay kesit bağımlılığını ve eş-bütünleşme denklemindeki yapısal kırılmaları göz önünde bulunduran "çoklu yapısal kırılmalı eş-bütünleşme testi"yle (Multiple Structural Break Cointegration test) analiz edilmiştir. Uzun ve kısa döneme ait bireysel ve panelin geneline ait eşbütünleşme katsayıları; Pesaran (2006) tarafından geliştirilen ve yatay kesit bağımlılığını (crossectional dependency) göz önünde bulunduran CCE (Common Corelated Effect-Ortak Ilişkili Etkiler) ve CCEMG (Common Corelated Effects Mean Group- Yatay kesit bağımlılı̆ı altında ortalama grup etkileri) yöntemiyle hesaplanmıştır. 


\section{ANALIZ}

\subsection{Veri Seti}

Analizde; Avrupa Birliği'ne üye 15 ülke (AB-15) ve Türkiye'ye ait, 1970-2011 dönemi verileri kullanılmıştır. Çalışmada; toplam yurt içi yatırımlar (Sabit sermaye oluşumu-INV) ve toplam yurt içi tasarruflar (SAV) verileri yıllık olarak alınmış, ülkelerin Gayri Safi Yurt içi Hasılalarına (GSYIH) oranlanarak kullanılmıştır. Veriler Dünya Bankası web sayfasından (www.worldbank. org.tr) ve IMF'nin veri tabanı olan International Financial Statistics'ten (IFS) elde edilmiştir. Analiz için Gauss-9 ve Stata-11 paket programı kullanılmıştır.

\subsection{Yatay Kesit Bağımlılığının Test Edilmesi}

Paneli oluşturan ülkelerin yani yatay kesitlerin birimlerinin bağımsız olması; paneli oluşturan birimlerden birine gelen şoktan, tüm yatay kesit birimlerinin aynı düzeyde etkilendikleri ve ülkelerin herhangi birinde meydana gelen bir makroekonomik şoktan diğer ülkelerin etkilenmediği varsayımına dayanmaktadır. Hâlbuki günümüzde ulus ekonomilerinin birbiriyle ilişkili olduğu düşünülürse, paneli oluşturan yatay kesit birimlerinden birine gelen bir şoktan, birimlerin farklı düzeyde etkilenmesi daha gerçekçi bir yaklaşımdır.

Seriler arasında yatay kesit bağımlılığı (YKB) varken, bu durum dikkate alınmadan analiz yapılması elde edilecek sonuçları önemli ölçüde etkilemektedir (Breusch and Pagan, 1980; Pesaran, 2004). Bu nedenle analize başlamadan önce, serilerde ve eş-bütünleşme denkleminde yatay kesit bağımlılığının varlığının test edilmesi gerekmektedir. YKB'nin yapılacak birim kök ve eş-bütünleşme testleri seçilirken göz önünde bulundurulması; yapılan analizin sonuçlarını sapmalı ve tutarsız hale getirecektir.

Seriler arasında YKB'nin varlığı; Berusch-Pagan (1980) LM testiyle ya da Pesaran (2004) CD testiyle incelenebilmektedir. Berusch-Pagan (1980) LM testi zaman boyutu yatay kesit boyutundan büyük olduğunda (T>N), Pesaran (2004) CD testi ise hem zaman boyutu yatay kesit boyutundan büyük hem de yatay kesit boyutu zaman boyutundan büyük durumda $(\mathrm{T}>\mathrm{N}, \mathrm{N}>\mathrm{T}$ ) kullanılabilmektedir. Bu testler, grup ortalaması sıfır fakat bireysel ortalama sıfırdan farklı olduğunda, sapmalı olmaktadır. Pesaran vd. (2008), bu sapmayı, test istatistiğine varyansı ve ortalamayı da ekleyerek düzeltmiştir. Bu nedenle ismi sapması düzeltilmiş LM testi olarak ifade edilmektedir $\left(\mathrm{LM}_{\mathrm{adj}}\right)$. LM test istatistiği ilk haliyle aşağıdaki gibidir.

$$
C D L M 1=T \sum_{i=1}^{N-1} \sum_{j=i+1}^{N} \hat{\rho}_{i j}^{2} \sim \chi_{\frac{N(N-1)}{2}}^{2}
$$

Daha sonra yapılan düzeltmeyle şu hale gelmiştir.

$$
\begin{gathered}
L M_{a d j}=\left(\frac{2}{N(N-1)}\right)^{1 / 2} \sum_{i=1}^{N-1} \\
\sum_{j=i+1}^{N} \hat{\rho}_{i j}^{2} \frac{(T-K-1) \hat{\rho}_{i j}-\hat{\mu}_{T i j}}{v_{T i j}} \sim N(0,1)
\end{gathered}
$$

Burada; $\hat{\mu}_{T i j}$ ortalamayı, $v_{T i j}$ varyansı temsil etmektedir. Buradan elde edilecek olan test istatistiği, asimtotik olarak standart normal dağılım göstermektedir (Pesaran, vd. 2008). Testin hipotezleri:

$H_{0}$ : Yatay kesit bağımlılığı yoktur.

$H_{1}$ : Yatay kesit bağımlılığı vardır.

Test sonucunda elde edilecek olasılık değeri 0.05 'ten küçük olduğunda, $\% 5$ anlamlılık düzeyinde, $H_{0}$ hipotezi reddedilmekte ve paneli oluşturan birimler arasında yatay kesit bağımlılığı olduğuna karar verilmektedir (Pesaran, 2008). Bu çalışmada, değişkenlerde ve eş-bütünleşme denkleminde yatay kesit bağımlıı̆̆ının varlığı, LM $\mathrm{Ldj}_{\mathrm{j}}$ testi ile kontrol edilmiş ve Tablo 1'deki sonuçlar elde edilmiştir.

Tablo 1: Yatay Kesit Bağımlılığı $\left(\mathrm{LM}_{\text {adj }}\right)$ Testi Sonuçları

\begin{tabular}{|c|c|c|c|}
\hline Değişkenler & INV & SAV & $\begin{array}{c}\text { Eş-Bütünleşme } \\
\text { Denklemi }\end{array}$ \\
\hline & \multicolumn{3}{|c|}{ Test İstatistiği ve Olasılık Değeri } \\
\hline LM & $386.50(0.00)$ & $671.62(0.00)$ & $750.58(0.00)$ \\
\hline CD & $14.19(0.00)$ & $21.42(0.00)$ & $14.62(0.00)$ \\
\hline LM $_{\text {adj }}$ & $193.47(0.00)$ & $190.68(0.00)$ & $16.68(0.00)$ \\
\hline
\end{tabular}

Tablo 1'den izlenebileceği gibi; toplam yatırımlar (INV) ve toplam tasarruflar (SAV) değişkenlerine ait olasılık değerleri 0.05 'ten küçük olduğu için, $\mathrm{H}_{0}$ hipotezleri, güçlü biçimde reddedilmiş, serilerde ve eşbütünleşme denkleminde yatay kesit bağımlılığının olduğuna karar verilmiştir. Bu durumda paneli oluşturan ülkeler arasında, YKB vardır. Ülkelerden birine gelen bir yatırımlardaki veya tasarruflardaki şok, diğer ülkeleri de etkilemektedir. Bu nedenle, bu ülkelerdeki karar vericiler yatırım-tasarruf politikalarını belirlerken, diğer ülkelerin uyguladıkları politikaları ve bu ülkeleri etkileyen şokları da göz önünde bulundurmalıdırlar. Ayrıca, çalışmada kullanılan INV ve SAV serileri için, analizin bundan sonraki aşamalarında birim kök testi testi yapılırken, YKB'yi dikkate alan testler kullanılmalıdır. Seriler arasında eşbütünleşme ilişkisinin varlığı ve eşbütünleşme denklemi tahmin edilirken ise yatay kesit bağımlılığını dikkate alan test yöntemlerinin kullanılması gerekmektedir. Bu yüzden çalışmanın bundan sonraki aşamalarında, YKB'yi dikkate alan panel birim kök testleri ve eş-bütünleşme analizi yöntemleri kullanılmıştır. 


\subsection{Panel Birim Kök Testi}

Verinin hem zaman hem de yatay kesit boyutuna ilişkin bilgiyi dikkate alan panel birim kök sınamalarının, sadece zaman boyutuyla ilgili bilgiyi göz önüne alan zaman serisi birim kök sınamalarından, istatistiksel anlamda daha güçlü olduğu kabul edilmektedir (Im, Pesaran ve Shin, 2003; Maddala ve Wu, 1999; Taylor ve Sarno, 1998; Levin, Lin ve Chu, 2002; Hadri, 2000; Pesaran, 2006; Beyaert ve Camacho, 2008). Çünkü yatay kesit boyutunun analize eklenmesiyle, verideki değişkenlik artmaktadır.

Panel birim kök sınamasında karşılaşılan ilk sorun, paneli oluşturan yatay kesitlerin birbirinden bağımsız olup olmadıklarıdır. Panel birim kök testleri bu noktada; birinci ve ikinci kuşak testler olmak üzere ikiye ayrılmaktadır. Birinci kuşak testler de homojen ve heterojen olmak üzere ikiye ayrılmaktadır. Homojen ve heterojenlik varsayımı paneli oluşturan ülkelerin seçimi ile ilgilidir. Birim kök analizlerinde eğer seçilen ülkeler benzer özellikte ise homojenliği, farklı özellikte ise heterojenliği varsayan testler kullanılmalıdır. Levin, Lin ve Chu (2002), Breitung (2005) ve Hadri (2000) homojenlik varsayımına dayanırken; Im, Pesaran ve Shin (2003), Maddala ve Wu (1999), Choi (2001) heterojenlik varsayımına dayanmaktadır.

Birinci kuşak birim kök testleri, paneli oluşturan yatay kesit birimlerinde YKB olmadığı varsayımına dayanmaktadır. Fakat günümüzde ülkelerin birbiriyle ilişkili olduğu düşünülürse, paneli oluşturan yatay kesit birimlerinde YKB'nin varlığı ve ülkelerden birine gelen bir şoktan, diğer ülkelerin farklı düzeylerde etkilenmesi daha rasyonel bir yaklaşımdır. Bu eksikliği gidermek için, yatay kesit birimleri arasındaki YKB'yi göz önünde bulundurarak birim kök analizi yapan ikinci nesil birim kök testleri geliş̧tirilmiştir. Başıca ikinci nesil birim kök testleri ise MADF (Taylor ve Sarno, 1998), SURADF (Breuer, Mcknown ve Wallace, 2002), Bai ve Ng (2004), CADF (Pesaran, 2006) ve PANKPSS (Carrion-i-Silvestre vd. 2005)'tir.

Yapısal kırılma olduğu halde yapısal kırılmalara yer vermeyen testler yanlış biçimde birim kök olduğu yönünde sapmalı sonuçlar vermektedir (Charemza ve Deadman, 1997). Bu çalışmada kullanılan INV ve SAV değişkenleri için paneli oluşturan ülkeler arasında YKB tespit edildiği için serilerin durağanlığı, YKB'yi ve ayrıca diğer birim kök testlerinden farklı olarak serilerdeki yapısal kırılmaları da göz önünde bulunduran, ikinci kuşak birim kök testlerinden Carrion-i-Silvestre vd. (2005) tarafından geliştirilen PANKPSS testi ile incelenmiştir. PANKPSS testi ile paneli oluşturan serilerin ortalama ve trendlerinde yapısal kırılmaların varlığı durumunda, serilerin durağanlığı test edilebilmektedir. Ayrıca, paneli oluşturan her bir yatay kesit biriminde farklı tarihlerde ve farklı sayılarda yapısal kırılmanın ortaya çıkmasına da izin vermektedir. Böylece serilerin durağanlığı, panelin geneli için ve her bir yatay kesit için ayrı ayrı da hesaplanabilmektedir. Test modeli şöyledir:

$$
\begin{aligned}
& Y_{i, t}=\alpha_{i, t}+\beta_{i, t} t+\varepsilon_{i, t} \\
& i=1,2, \ldots ., N \text { ve } t=1,2, \ldots ., T
\end{aligned}
$$

Burada $\alpha_{i, t}$ ve $\beta_{i, t}$

$\alpha_{i, t}=\sum_{k=1}^{m_{1}} \theta_{i, k} D 1_{i, t}+\sum_{k=1}^{m_{1}} \gamma_{i, k} D 2_{i, t}+\alpha_{i, t-1}+u_{i, t}$

$\beta_{i, t}=\sum_{k=1}^{n_{1}} \varphi_{i, k} D 1_{i, t}+\sum_{k=1}^{n_{1}} \gamma_{i, k} D 2_{i, t}+\beta_{i, t-1}+v_{i, t}$

şeklindedir. D1 ve D2 kukla değişkenler olup, aşağıdaki şekilde tanımlanabilir.

$$
\begin{aligned}
& D 1=\left\{\begin{array}{lr}
1, & t=T_{B}+1 \\
0, & \text { dĭg } \text { er durumlarda }
\end{array}\right. \\
& D 2=\left\{\begin{array}{lr}
1, & t>T_{B}+1 \\
0, & \text { diğer durumlarda }
\end{array}\right.
\end{aligned}
$$

Bu denklemde $T_{B^{\prime}}$ kırılma noktasını ifade etmekte olup, sabit terimde $\mathrm{m}$ tane, trendde $\mathrm{n}$ tane yapısal kırilmaya izin vermektedir. Carrion-i-Silvestre vd. (2005), en fazla 5 tane yapısal kırılmaya izin verecek şekilde düzenlenmiştir. Bu test, yapısal kırılma tarihlerini BaiPerron (1998)'i izleyerek, hata kareler toplamının (SSR) minimize olduğu noktalar olarak tespit etmektedir. Bai-Perron (1998) iki farklı süreç önermiştir: Birincisi; Liu, Wu ve Zidek (1997) tarafından geliştirilen değiştirilmiş Schwarz bilgi kriterine (LWZ) dayanmakta, ikincisi yapısal kırılma sayısının belirlenmesi için ard arda $\mathrm{F}$ istatistiğinin hesaplanmasına dayanmaktadır. Carrion-iSilvestre vd. (2005), yapısal kırılma sayısını belirlerken, trendli model için birinci süreci, trendsiz model için ikinci süreci kullanmaktadır. Testin hipotezleri şöyledir:

$H_{0}$ : Seri Durağandır.

$H_{i}$ : Seri Durağan Değildir.

Hesaplanan test istatistikleri, yatay kesit bağımlıı̆ının varlığı durumunda Bootstrap ile hesaplanan kritik değerlerle, yokluğu durumunda ise asimtotik olarak standart normal dağılım olasılık değerleri ile karşılaştırilır. Hesaplanan test istatistiği, kritik değerinden büyük olduğunda, $H_{0}$ reddedilir ve serinin durağan olmadığına karar verilir. Paneli oluşturan her ülke için ve panelin geneli için test istatistikleri ve kritik değerler hesaplanmış ve elde edilen sonuçlar Tablo 2 'de verilmiştir. 
Tablo 2: Panel Birim Kök Testi (PANKPSS) Sonuçları

\begin{tabular}{|l|c|c|c|c|c|c|c|c|}
\hline \multicolumn{1}{|c|}{ Değişkenler } & \multicolumn{2}{c|}{ INV } & \multicolumn{2}{c|}{$\Delta I N V$} & \multicolumn{2}{c|}{ SAV } & \multicolumn{2}{c|}{$\Delta$ SAV } \\
\hline & Test İst. & $\begin{array}{c}\text { Kritik } \\
\text { Değerler }\end{array}$ & Test İst. & $\begin{array}{c}\text { Kritik } \\
\text { Değerler }\end{array}$ & Test İst. & $\begin{array}{c}\text { Kritik } \\
\text { Değerler }\end{array}$ & Test İst. & $\begin{array}{c}\text { Kritik } \\
\text { Değerler }\end{array}$ \\
\hline Avusturya & 0.173 & 0.950 & $0.126^{*}$ & 0.950 & $0.029^{*}$ & 0.950 & $0.206^{*}$ & 0.950 \\
\hline Belçika & $0.055^{*}$ & 0.094 & $0.065^{*}$ & 0.512 & $0.071^{*}$ & 0.176 & $0.120^{*}$ & 0.509 \\
\hline Danimarka & $0.068^{*}$ & 0.116 & $0.060^{*}$ & 0.566 & $0.039^{*}$ & 0.121 & $0.072^{*}$ & 0.592 \\
\hline Finlandiya & $0.026^{*}$ & 0.081 & $0.218^{*}$ & 0.501 & 0.278 & 0.175 & $0.066^{*}$ & 0.543 \\
\hline Fransa & $0.050^{*}$ & 0.188 & $0.104^{*}$ & 0.569 & $0.017^{*}$ & 0.069 & $0.142^{*}$ & 0.531 \\
\hline Almanya & $0.049^{*}$ & 0.114 & 0.709 & 0.519 & $0.027^{*}$ & 0.101 & $0.339^{*}$ & 0.606 \\
\hline Yunanistan & $0.057^{*}$ & 0.081 & $0.201^{*}$ & 0.573 & $0.117^{*}$ & 0.186 & $0.420^{*}$ & 0.669 \\
\hline İrlanda & $0.023^{*}$ & 0.189 & $0.196^{*}$ & 0.529 & $0.160^{*}$ & 0.179 & $0.192^{*}$ & 0.526 \\
\hline İtalya & 0.313 & 0.105 & 1.595 & 0.539 & $0.030^{*}$ & 0.109 & $1.013^{*}$ & 1.363 \\
\hline Lüksemburg & $0.060^{*}$ & 0.094 & $0.138^{*}$ & 0.814 & $0.076^{*}$ & 0.142 & $0.293^{*}$ & 0.694 \\
\hline Hollanda & $0.137^{*}$ & 0.174 & 0.794 & 0.512 & $0.103^{*}$ & 0.166 & $0.133^{*}$ & 0.610 \\
\hline Portekiz & $0.133^{*}$ & 0.195 & 0.902 & 0.647 & 0.171 & 0.155 & $0.356^{*}$ & 0.553 \\
\hline İspanya & $0.059^{*}$ & 0.101 & $0.225^{*}$ & 0.533 & $0.070^{*}$ & 0.219 & $0.917^{*}$ & 0.507 \\
\hline İsveç & $0.040^{*}$ & 0.139 & $0.041^{*}$ & 0.576 & 0.071 & 0.059 & $0.103^{*}$ & 0.831 \\
\hline İngiltere & 0.282 & 0.105 & $0.069^{*}$ & 0.492 & $0.176^{*}$ & 0.090 & 0.573 & 0.557 \\
\hline Türkiye & $0.024^{*}$ & 0.055 & $0.053^{*}$ & 0.497 & $0.061^{*}$ & 0.213 & $0.280^{*}$ & 0.513 \\
\hline Panel & 23.71 & 17.49 & $4.84^{*}$ & 6.00 & 13.33 & 12.02 & $4.21^{*}$ & 7.76 \\
\hline
\end{tabular}

(Not: Kritik değerler, Bootstrapla 1000 döngü ile üretilmiş değerlerdir. *; \%5 anlamlılık düzeyinde serinin durağan olduğunu ifade etmektedir. Test modeli olarak, sabitte ve trendde yapısal kırılmaya izin veren model seçilmiştir)

Tablodaki sonuçlar incelendiğinde, panelin geneli için, serilerin düzeyde durağan olmayıp, birinci farkları alındığında durağan hale geldiği yani, I(1) oldukları görülmüştür. Bu durumda, bu seriler arasındaki eşbütünleşme ilişkisinin incelenebileceğine karar veril-

miştir. Çünkü eş-bütünleşme analizinin yapılabilmesi için serilerin I(1) olması ön koşuldur. Birim kök analizinde ayrıca serilere ait kırılma tarihleri de belirlenmiştir. Belirlenen kırılma tarihleri Tablo 3'te verilmiştir.

Tablo 3: Serilerin Kırılma Tarihleri

\begin{tabular}{|l|c|c|c|c|c|c|c|c|}
\hline & \multicolumn{4}{|c|}{ INV } & \multicolumn{5}{c|}{ SAV } \\
\hline & \multicolumn{3}{|c|}{ Kırılma Tarihleri } & \multicolumn{3}{c|}{ Kılma Tarihleri } \\
\hline Avusturya & 1981 & 1994 & - & - & 1984 & - & - & - \\
\hline Belçika & 1980 & 1987 & - & - & 1980 & 1987 & 2005 & - \\
\hline Danimarka & 1980 & 1986 & 1994 & 2005 & 1983 & - & - & - \\
\hline Finlandiya & 1991 & - & - & - & 1990 & 2000 & - & - \\
\hline Fransa & 1982 & 1992 & - & - & 1980 & 1997 & - & - \\
\hline Almanya & 1977 & 1989 & 2001 & - & 1982 & - & - & - \\
\hline Yunanistan & 1998 & - & - & - & 2003 & - & - & - \\
\hline İrlanda & 1978 & 1987 & 2005 & - & 1979 & 2004 & - & - \\
\hline İtalya & 1982 & 1992 & 2005 & - & 1980 & 1994 & 2005 & - \\
\hline Lüksemburg & 1986 & - & - & - & - & - & - & - \\
\hline Hollanda & 1984 & - & - & - & 1983 & - & - & - \\
\hline Portekiz & 1983 & 1997 & - & - & 1976 & 1986 & - & - \\
\hline İspanya & 1986 & 1992 & 2005 & - & 1980 & 1988 & 1994 & 2002 \\
\hline İsveç & 1988 & 1994 & - & - & 1982 & 1990 & - & - \\
\hline İngiltere & 1980 & 1990 & 2005 & - & 1995 & - & - & - \\
\hline Türkiye & 1986 & - & - & - & 1986 & - & - & - \\
\hline
\end{tabular}

(Not: Yapısal kırılma tarihleri Bootstrap ile 1000 döngü ile tespit edilmiştir. Maksimum kırılma sayısı 5 alınmıştır. Test modeli olarak, sabitte ve trendde yapısal kırılmaya izin veren model seçilmiştir.)

Test yöntemi, yatırım ve tasarruf verileri için Türkiye'deki yapısal kırılmayı başarıyla tespit etmiştir. 1986 yılı Türkiye'de borsanın işlem görmeye başladığı tarihtir. Ayrıca 1980 'den itibaren uygulanan ithal ikameci politika yerine ihracata dayalı büyüme stratejisinin uygulanmasıyla ticaret rejiminin liberalleşmesinden sonra, sermaye hesabının da liberalleşme sürecine işaret etmektedir.

\subsection{Eş-bütünleşme Katsayılarının Homojenliğinin Test Edilmesi}

Eş-bütünleşme denkleminde eğim katsayısının homojen olup olmadığını belirlemeye yarayan bir testtir. Bu konudaki ilk çalışmalar, Swamy (1970) ile başlamıştır. Pesaran ve Yamagata (2008), Swamy testini geliştirmiştir. Bu testte; 


$$
Y_{i t}=\alpha+\beta_{i} X_{i t}+\varepsilon_{i t}
$$

şeklindeki genel bir eş-bütünleşme denkleminde,

$\beta_{i}$ eğim katsayılarının, yatay kesitler arasında farklı olup olmadığını test edilmektedir. Testin hipotezleri şu şekildedir.

$H_{0}: \beta_{i}=\beta$ Eğim katsayıları homojendir.

$H_{i}: \beta_{i} \neq \beta \quad$ Eğim katsayıları homojen değildir.

(5) no.lu regresyon modelini önce panel EKK (En Küçük Kareler Yöntemi) ile sonra da Ağırlıklandırılmış Sabit Etkiler modeli ile tahmin ederek, gerekli test istatistiğini oluşturmaktadır. Pesaran and Yamagata (2008), hipotezleri test edebilmek için iki farklı test istatistiği geliştirmiştir:

Büyük Örneklemler İçin: $\widehat{\Delta}=\sqrt{N}\left(\frac{N^{-1} s+k}{2 k}\right) \sim \chi_{k}^{2}$

Küçük Örneklemler İçin: $\widehat{\Delta}_{a d j}=\sqrt{N}\left(\frac{N^{-1} \dot{s}-k}{v(T, k)}\right) \sim N(0,1)$

Burada N; yatay kesit sayısını, S; Swamy test ista-

tistiğini, k; açıklayıcı değişken sayısını ve $v(T, k)$ standart hatayı ifade etmektedir. Homojenlik testi sonuçları, Tablo 4'te verilmiştir.

Tablo 4: Homojenlik Testi Sonuçları

\begin{tabular}{|c|c|c|}
\hline & Test İstatistiği & Olasılık Değeri \\
\hline$\widehat{\Delta}$ & 5.149 & 0.000 \\
\hline$\widehat{\Delta}_{\text {adj }}$ & 5.339 & 0.000 \\
\hline
\end{tabular}

Tablo 4'te hesaplanan testlerin olasılık değerleri 0.05 'ten küçük olduğu için, $\mathrm{H}_{0}$ reddedilmiştir. Eş bütünleşme denkleminde, sabit terim ve eğim katsayılarının homojen olmadığına karar verilmiştir. Bu durumda, paneldeki ülkeler için yapılacak eş-bütünleşme yorumları geçerlidir ve güvenilebilir (Pesaran and Yamagata, 2008).

\subsection{Yapısal Kırılmalı Panel Eş-Bütünleşme Testi}

Basher ve Westerlund (2009) tarafından geliştirilen bu test, yatay kesit bağımlılığının olduğu durumda yapısal kırılmaları dikkate alarak, düzeyde durağan olmayan fakat birinci farkı alındığı zaman durağan olan seriler arasında eş-bütünleşme ilişkisinin varlığı$\mathrm{n}$ t test etmektedir. Bu test sabit terimde ve trendde kırılmalara izin vermektedir. Geliştirilen test istatistiği denklem (6)'da verilmiştir.

$$
Z(M)=\frac{1}{N} \sum_{i=1}^{N} \sum_{J=1}^{M_{i}+1} \sum_{t=T_{i j-1}+1}^{T_{i j}} \frac{s_{i t}^{2}}{\left(T_{i j}-T_{i j-1}\right)^{2} \widehat{\sigma}_{i}^{2}}
$$

burada $S_{i t}=\sum_{s=T_{i j-1}+1}^{t} \widehat{W}_{s t}$ dir. $\widehat{W}_{s t}$ ise tam değiştirilmiş EKK türü etkín bir tahminciden elde edilmiş kalıntılar vektörüdür $\hat{\sigma}_{i}^{2}$ de $\widehat{W}_{s t}$ ye dayalı uzun dönem varyans tahmincisidir. $Z(M)$ yatay kesit ortalamaları alınarak sadeleştirildiğinde aşağıdaki şekle gelir.

$$
Z(M)=\sum_{t=T_{i j-1}+1}^{T_{i j}} \frac{s_{i t}^{2}}{\left(T_{i j}-T_{i j-1}\right)^{2} \hat{\sigma}_{i}^{2}} \sim N(0,1)
$$

Elde edilen bu test istatistiği, standart normal dağılım göstermektedir. Testin hipotezleri:

$H_{0}$ : Seriler arasında eş-bütünleşme ilişkisi vardır.

$H_{1}$ : Bazı yatay kesitler için, seriler arasında eşbütünleşme ilişkisi yoktur.

Eş-bütünleşme ilişkisi incelenirken, paneli oluşturan ülkeler arasında YKB olmadığında, hesaplanan LM test istatistiği 1.645 kritik değeri ile karşılaştırılır ya da asimtotik olasılık değeri 0.05 ile karşılaştırılır. YKB olduğunda ise hesaplanan bootstrap olasılık değerleri, 0.05 ile karşılaştırılmaktadır (\%5 anlamlılık düzeyi için). Hesaplanan testin olasılık değeri, 0.05 'ten büyük olduğunda, $\mathrm{H}_{0}$ kabul edilmekte ve seriler arasında eşbütünleşme ilişkisinin varlığına karar verilmektedir. Eş-bütünleşme test sonuçları Tablo 5'te görülmektedir.

Tablo 5: Çoklu Yapısal Kırılmalı Panel Eş-Bütünleşme Test Sonuçları

\begin{tabular}{|l|c|c|c|c|c|}
\hline & $\begin{array}{c}\text { LM Test } \\
\text { İstatistiği }\end{array}$ & $\begin{array}{c}\text { Asimtotik } \\
\text { Olasılık Değeri }\end{array}$ & Karar & $\begin{array}{c}\text { Boostrap } \\
\text { Olasılık Değeri }\end{array}$ & Karar \\
\hline Kırılmalar Dikkate Alınmazsa: & 15.916 & 0.000 & Eşbütünleşme yoktur & 0.000 & Eşbütünleşme yoktur \\
\hline Sabitte & 4.496 & 0.000 & Eşbütünleşme yoktur. & 0.002 & Eşbütünleşme yoktur \\
\hline Sabitte ve Trendde & \multicolumn{5}{|l|}{} \\
\hline Kırılmalar Dikkate Alınırsa: \\
\hline Sabitte & 6.520 & 0.000 & Eşbütünleşme yoktur. & 0.748 & Eş-bütünleşme vardır. \\
\hline Sabitte ve Trendde & -347.68 & 1.000 & Eş-bütünleşme vardır. & 0.968 & Eş-bütünleşme vardır. \\
\hline
\end{tabular}

(Not: Olasılık değerleri, Bootstrap kullanılarak 1000 örneklem ile elde edilmiştir.) 
Tablodaki sonuçlar incelendiğinde, YKB'nin ve yapısal kırılmaların dikkate alınıp alınmaması, eşbütünleşme ilişkisinin varlığı konusundaki kararı önemli ölçüde etkilemektedir. Örneğin sabitte yapısal kırılmaların dikkate alındığı seçenekte, YKB'nin olmadığı durumda seriler arasında eşbütünleşme ilişkisi yokken (olasılık değeri=0.000), YKB'nın olduğu durumda ise eşbütünleşme ilişkisinin olduğu görülmektedir (olasılık değeri=0.748). Benzer şekilde, YKB'nin dikkate alındığı seçenekte, sabitte kırılmaların olmadığı durumda seriler arasında eşbütünleşme ilişkisi yokken (olasılık değeri=0.000), kırılmaların olduğu durumda ise eşbütünleşme ilişkisinin olduğu görülmektedir (olasılık değeri=0.748). Burada ülkeler arasındaki YKB ve eş-bütünleşme denklemlerindeki yapısal kırılmalar göz önünde bulundurulduğunda, panelin genelinde seriler arasında eş-bütünleşme ilişkisinin var olduğuna karar verilmiş̧ir.

Tablo 6: Eş-bütünleşme Denkleminde AB-15 Ülkeleri ve Türkiye'nin Yapısal Kırılma Sayıları ve Tarihleri

\begin{tabular}{|l|c|c|c|c|c|c|}
\hline Ülkeler & $\begin{array}{c}\text { Kirıma } \\
\text { Sayıları }\end{array}$ & \multicolumn{5}{|c|}{ Kırılma Tarihleri } \\
\hline Avusturya & 2 & 1981 & 1993 & - & - & - \\
\hline Belçika & 2 & 1981 & 2001 & - & - & - \\
\hline Danimarka & 5 & 1980 & 1986 & 1992 & 1998 & 2005 \\
\hline Finlandiya & 3 & 1976 & 1988 & 1994 & - & - \\
\hline Fransa & 4 & 1976 & 1982 & 1991 & 1998 & - \\
\hline Almanya & 4 & 1975 & 1981 & 1989 & 2001 & - \\
\hline Yunanistan & 2 & 1976 & 1998 & - & - & - \\
\hline İrlanda & 4 & 1978 & 1985 & 1995 & 2005 & - \\
\hline İtalya & 4 & 1975 & 1982 & 1992 & 2005 & - \\
\hline Lüksemburg & 3 & 1979 & 1985 & 1998 & - & - \\
\hline Hollanda & 5 & 1976 & 1982 & 1989 & 1997 & 2005 \\
\hline Portekiz & 2 & 1983 & 1997 & - & - & - \\
\hline İspanya & 5 & 1975 & 1983 & 1989 & 1995 & 2005 \\
\hline İsveç & 2 & 1988 & 1994 & - & - & - \\
\hline İngiltere & 4 & 1975 & 1982 & 1990 & 1998 & - \\
\hline Türkiye & 3 & 1980 & 1997 & 2003 & - & - \\
\hline & 5 & & - & - \\
\hline
\end{tabular}

(Not: Kırılmalar bulunurken sabit ve trendde kırılmaya izin veren model kullanılmıştır. Yapısal kırılma tarihleri, Bootstrap kullanılarak 1000 döngü ile elde edilmiştir. Maksimum kırılma sayısı 5 alınmıştır.)

Tablo 6'dan izlenebileceği gibi, yatııım-tasarruf ilişkisinin incelendiği eşbütünleşme denkleminde Türkiye için yapısal kırılma tarihleri 1980, 1997 ve 2003'tür.
1980 ithal ikameci sanayileşme politikası yerine ihracata dayalı büyüme stratejisinin uygulandığı ve askeri darbe dönemini belirtir. 1997 yılı 1989'da sermaye hesabının liberalleşmesinden sonra Türkiye'nin döviz ve bankacılık krizleri ile uğraştığı yıldır. 2003 yılı ise; 2001 krizi sonrası dalgalı kura geçilmesi, bankacılık alanında yapılan kapsamlı düzenlemeler, güçlü ekonomiye geçiş programının uygulanmaya başlanması ve tek parti iktidarının olduğu yılı işaret etmektedir. Elde edilen yapısal kırılma noktaları, eş-bütünleşme katsayılarının tahmini işleminde, kukla değişkenlerle analize dâhil edilmiştir. Kukla değişkenler oluşturulurken, birinci kukla değişken için paneli oluşturan ülkelerdeki birinci kırılma tarihi için " 1 ", diğer yıllar için " 0 " değeri verilmiş ve kukla oluşturma işlemi diğer dört kukla değişken için de benzer şekilde uygulanmıştır.

\subsection{Uzun Dönem Eş-Bütünleşme Katsayılarının} Tahmin Edilmesi

Çalışmanın bu kısmında, seriler arasında eşbütünleşme ilişkisi tespit edildikten sonra uzun dönem bireysel eşbütünleşme katsayıları; Pesaran (2006) tarafından geliştirilen ve yatay kesit bağımlılığını göz önünde bulunduran CCE ile denklem (8) yardımıyla tahmin edilecektir. Bu analizde, eş-bütünleşme analizinde elde edilen yapısal kırılma noktaları, kukla değişkenlerle analize dâhil edilmiştir. CCE; zaman boyutu, yatay kesit boyutundan büyük olduğunda da küçük olduğunda da tutarlı ve asimtotik normal dağılım sağlayan sonuçlar üretebilen ve yatay kesit birimleri için ayrı ayrı uzun dönem denge değerlerini hesaplayabilen bir tahmincidir (Pesaran, 2006). Panelin geneli için geçerli olacak olan uzun dönem eş-bütünleşme katsayısı ise, uzun dönem eş-bütünleşme parametrelerinin homojen olduğu varsayımı altında, Pesaran (2006) tarafından geliştirilen CCEMG yöntemi ile hesaplanmıştır. CCEMG, gruplara ait değerlerin aritmetik ortalamasını alarak, uzun dönem eş-bütünleşme katsayısını tahmin etmektedir. CCE ve CCEMG tahminleri yapılmış ve sonuçlar, Tablo 7'da veriliştir.

$$
\begin{aligned}
& I N V_{i t}=\beta_{0 i}++\beta_{1 i} S A V_{i t}+\beta_{2 i} D_{1_{i t}}+\beta_{3 i} D_{2_{i t}} \\
& +\beta_{4 i} D_{3_{i t}}+\beta_{5 i} D_{4 i t}+\beta_{6 i} D_{5_{i t}}+\varepsilon_{i t}
\end{aligned}
$$


Tablo 7: Uzun Dönem Eş-Bütünleşme Katsayıları

\begin{tabular}{|l|c|c|}
\hline \multicolumn{1}{|c|}{ Ülkeler } & $\mathrm{SAV}^{*}$ & t-ist. \\
\hline Avusturya & 0.008 & 0.07 \\
\hline Belçika & 0.681 & $8.81^{*}$ \\
\hline Danimarka & 0.321 & $2.59^{*}$ \\
\hline Finlandiya & 0.182 & $1.31^{* * *}$ \\
\hline Fransa & 0.557 & $4.42^{*}$ \\
\hline Almanya & 0.065 & 0.37 \\
\hline Yunanistan & 0.090 & $1.39^{* * *}$ \\
\hline İrlanda & 0.571 & $3.84^{*}$ \\
\hline İtalya & 0.460 & $3.64^{*}$ \\
\hline Lüksemburg & -0.054 & -0.44 \\
\hline Hollanda & 0.013 & 0.07 \\
\hline Portekiz & 0.210 & $4.43^{*}$ \\
\hline İspanya & 0.302 & 0.68 \\
\hline İsveç & 0.250 & $2.99^{*}$ \\
\hline İngiltere & 0.166 & $1.70^{* *}$ \\
\hline Türkiye & 0.786 & $7.32^{*}$ \\
\hline Panel & 0.288 & $4.51^{*}$ \\
\hline
\end{tabular}

Not: t istatistiğinin hesaplanmasında; Newey-West değişen varyans standart hatası kullanılmıştır. ${ }^{*},{ }^{* *},{ }^{* * *}$ ifadeleri sırasıyla \%1, \%5 ve \%10 anlamlılık düzeyini göstermektedir. $\Psi:$ SAV toplam yurtiçi tasarruflar değişkenidir.

Tablo 7'den izlenebileceği gibi; incelenen AB-15 ülkeleri ve Türkiye için beklentilerimizle uyumlu olarak toplam tasarrufların yatırımları arttırıcı yönde etkilediği görülmüştür. Panelin genelinde tasarruflar yatırımların \%28'ini finanse etmekte kalan kısmı ise dış tasarruflarla karşılanmaktadır. Diğer bir ifadeyle tasarruf oranının \%100 artması, yatırım oranını \%28 oranında arttıracaktır ve bu sonuç istatistiki olarak yorumlanabilir düzeydedir. İncelenen ülkelerin genelinde sermaye liberalizasyonunun olduğu ve analizde yatırımların önemli kısmının dış tasarruflarla gerçekleştiği göz önüne alınırsa F-H hipotezinin geçerli olduğu ifade edilebilir.

Ülkeler özelinde incelendiği incelenen on altı ülkeden on birinde tasarrufların katsayısı pozitif ve istatistiki olarak anlamlıdır. Yurt içi tasarrufların yatırımları karşılama oranının en yüksek olduğu ülkeler sırasıyla; Türkiye, Belçika, İrlanda, Fransa, İtalya, Danimarka, İsveç, Portekiz, Finlandiya, İngiltere ve Yunanistan'dır. Yurt içi tasarrufların yatırımları karşılama oranı; Türkiye'de \%78, Belçika'da \%68, İrlanda'da \%57, Fransa'da \%55, İtalya'da \%46, Danimarka'da $\% 32$, İsveç'te $\% 25$, Portekiz'de \%21, Finlandiya'da $\% 18$, Ingiltere'de $\% 16$ ve Yunanistan'da \%9'dur.

Avusturya, Almanya, Lüksemburg, Hollanda ve
İspanya'da tasarrufların katsayısı oldukça düşük değerdedir ve istatistiki olarak yorumlanabilir düzeyde değildir. İlgili AB üyesi ülkelerde sermaye hareketleri üzerinde kısıtlar bulunmamaktadır ve $\mathrm{F}-\mathrm{H}$ hipotezine göre yatırım-tasarruf ilişkisinin düşük düzeyde olması ya da ilişkinin hiç olmaması beklenmektedir. Bu ülkelerde tasarrufların katsayısının anlamsız olması ya da hipotezin geçerli olmaması bu bağlamda değerlendirilebilir. Nitekim F-H hipotezine göre, Türkiye gibi liberalizasyon sürecini diğer ülkelere göre daha geç tamamlayan ülkelerde yatırım-tasarruf ilişkisinin güçlü ve istatistiki olarak anlamlı olması hipotezin beklenen sonucudur.

Türkiye'de 1984 yılına kadar sermaye hareketleri, döviz işlemlerine ilişkin düzenlemelerle kontrol edilmekte idi. Sermaye hareketlerinin liberalleştirilmesi süreci, 1980'lerden sonra ihracata dayalı büyüme modeline geçilmesi ve ticaret rejiminin büyük ölçüde liberalleşmesinden sonra 28 ve 30 No'lu Kararnamelerle başlatılmış ve bu kararnameler doğrultusunda Aralık 1983 ve Temmuz 1984'te uygulamaya konmuştur. Bu tarihe kadar 1980 sonrası uygulanan yeni ekonomik modelle bağlantılı olarak uygulanan söz konusu kararnamelerle sermaye hareketleri kısmen liberalleștirilmiștir. Türkiye'de, sermaye hareketlerinin tamamen liberalleştirilmesi, 1989 yılında çıkarılan 32 No'lu Kararname ve ilgili düzenlemelerle tamamlanmış ve konvertibiliteye yönelik en önemli adımlar atılmıştır (TCMB, 2002: 16). Çalışmanın 1970-2011 dönemini kapsadığı göz önüne alınırsa sermaye hareketleri üzerinde kısıtların en fazla olduğu Türkiye'de tasarrufların yatırımları karşılama oranı F-H hipotezine paralel olarak en yüksek çıkmıştır.

\subsection{Kısa Dönem Katsayılarının Tahmin Edilmesi}

Çalışmanın bu kısmında, ülkelere ait kısa dönem katsayıları ve hata düzeltme terimleri (ECT) CCE ile panelin geneli için geçerli olan kısa dönem katsayısı ise, CCEMG yöntemi ile denklem (9)'da verilen hata düzeltme modeli yardımıyla hesaplanmıştır. Bu analizde, eş-bütünleşme analizinde elde edilen yapısal kırılma noktaları, kukla değişkenlerle analize dâhil edilmiştir. CCE ve CCEMG tahminleri yapılmış ve sonuçlar, Tablo 8'de veriliştir. $\Delta I N V_{i t}=\beta_{0 i}+\beta_{1 i} E C T_{i, t-1}+\beta_{2 i} \Delta S A V_{i t}+\beta_{3 i} D_{1_{i t}}+$

$D_{2_{i t}}+\beta_{5 i} D_{3_{i t}}+\beta_{6 i} D_{4 i t}+\beta_{7 i} D_{5_{i t}}+\varepsilon_{i t}$ 
Tablo 8: Kısa Dönem Katsayıları

\begin{tabular}{|l|c|c|c|c|}
\hline \multicolumn{1}{|c|}{ Ülke } & $\mathrm{ECT}_{\mathrm{t}-1}$ & $\mathrm{t}$-ist. & $\mathrm{SAV}^{*}$ & $\mathrm{t}$-ist. \\
\hline Avusturya & -0.171 & $-1.61^{* * *}$ & -0.102 & -0.66 \\
\hline Belçika & -0.115 & -0.93 & 0.430 & $2.43^{*}$ \\
\hline Danimarka & -0.317 & $-1.86^{* *}$ & 0.270 & $1.68^{* *}$ \\
\hline Finlandiya & -0.151 & $-1.60^{* * *}$ & 0.184 & $1.55^{* * *}$ \\
\hline Fransa & -0.126 & $-1.32^{* * *}$ & 0.383 & $1.98^{* *}$ \\
\hline Almanya & -0.037 & -0.50 & 0.369 & $2.44^{*}$ \\
\hline Yunanistan & -0.263 & $-1.93^{* *}$ & 0.215 & $1.49^{* * *}$ \\
\hline İrlanda & -0.023 & -0.21 & -0.014 & -0.12 \\
\hline İtalya & -0.885 & $2.92^{*}$ & 0.425 & $1.99^{* * *}$ \\
\hline Lüksemburg & -0.683 & $-5.52^{*}$ & 0.154 & $1.33^{* * *}$ \\
\hline Hollanda & -0.284 & $-2.66^{*}$ & -0.117 & -0.77 \\
\hline Portekiz & -0.412 & $-3.99^{*}$ & 0.067 & 1.23 \\
\hline İspanya & -0.019 & -0.24 & 0.050 & 0.51 \\
\hline İsveç & -0.304 & $-3.06^{*}$ & 0.250 & $2.38^{*}$ \\
\hline İngiltere & -0.142 & -0.69 & 0.262 & $2.44^{*}$ \\
\hline Türkiye & -0.169 & $-1.34^{* * *}$ & 0.577 & $4.62^{*}$ \\
\hline Panel & -0.256 & $-4.34^{*}$ & 0.212 & $4.26^{*}$ \\
\hline
\end{tabular}

(Not: $\mathrm{t}$ istatistiğinin hesaplanmasında; Newey-West değişen varyans standart hatası kullanılmıştır. ${ }^{*},{ }^{* *}$ ve ${ }^{* * *}$ ifadeleri sırasıyla $\% 1, \% 5$ ve $\% 10$ anlamlılık düzeyini göstermektedir. $\Psi:$ SAV toplam yurtiçi tasarruflar değişkenidir.)

Tablo 8'den izlenebileceği gibi panelin geneli için hata düzeltme teriminin katsayısı beklenildiği gibi negatif çıkmıştır ve istatistiki olarak anlamlıdır. Hata düzeltme teriminin katsayısı 0.25 olup, kısa dönemde seriler arasında meydana gelen sapaların her dönem $\% 25$ 'inin ortadan kalkacağını ve yaklaşık dört dönem² içinde uzun dönem dengesine yakınsayacağını ifade eder. Incelenen ülkelerin tümünde de hata düzeltme teriminin katsayısı beklenildiği gibi negatiftir ve on bir ülkede istatistiki olarak anlamlıdır. Panelin genelinde kısa dönemde tasarruflar yatırımların \%21'ini finanse etmekte kalan kısmı ise dış tasarruflarla karşılanmaktadır. Kısa dönemde tasarrufların yatırımlara etkisi uzun döneme kıyasla daha düşük düzeydedir.

\section{SONUÇ VE DEĞERLENDIRME}

Bu çalışmada, yurt içi toplam yatırımlar ile yurt içi toplam tasarruflar arasındaki ilişki Feldstein-Horioka hipotezi çerçevesinde, aynı entegrasyonda bulunan AB-15 ülkeleri ve Türkiye ekonomileri için, 1970-2011 dönemi yıllık verileri kullanılarak, serilerde ve modelde çoklu yapısal kırılmaları ve yatay kesit bağımlııı̆ını dikkate alan yani, incelenen ülkelerden herhangi birisinde meydana gelen makroekonomik şokun diğer ülkeleri de etkileyeceği varsayımını göz önünde bulunduran yapısal kırılmalı dinamik panel veri analizi yöntemleri kullanılarak incelenmiştir. Çalışmada yatırımlar ve tasarruflar, ülkelerin Gayri Safi Yurt içi Hasılalarına oranlanarak kullanılmıştır.
Analizde, paneli oluşturan ülkeler arasında yatay kesit bağımlılığı Pesaran vd. (2008) tarafından geliştirilen $L M_{\text {adj }}$ testi ile incelenmiş ve YKB tespit edilmiştir. Yani incelenen ülkelerden herhangi birisinde meydana gelen makroekonomik şok diğer ülkeleri de etkileyecektir. Bunun sebebi olarak bu ülkelerin Türkiye hariç hepsinin aynı entegrasyona üye olmaları düşünülebilir. Yatırım ve tasarruf serilerinde YBK tespit edildiği için birim kök ve eş-bütünleşme analizleri YKB'yi dikkate alan yeni nesil testlerle yapılmıştır. Serilerde birim kökün varlığı, Carrion-i-Silvestre vd. (2005) tarafından geliştirilen ve serilerdeki yapısal kırılmaları dikkate alan PANKPSS testiyle analiz edilmiş ve serilerin düzeyde durağan olmayıp, birinci farkları alındığında durağan hale geldikleri görülmüştür. Bu durumda seriler arasındaki eş-bütünleşme ilişkisinin incelenebilmesi için önkoşulun sağlandığı belirlenmiştir. Seriler arasında eş-bütünleşme ilişkisinin varlığı, Basher ve Westerlund (2009) tarafından geliştirilen, YKB ve yapısal kırılmaları dikkate alan test ile analiz edilmiş ve seriler arasında eş-bütünleşme ilişkisinin var olduğu belirlenmiştir.

Uzun dönem eş-bütünleşme katsayıları, Pesaran (2006) tarafından geliş̧irilen ve YKB'yi dikkate alan CCE yöntemiyle tahmin edilmiş ve paneli oluşturan ülkelerin genelinde zayıf eş-bütünleşme ilişkisi elde edilmiş ve eş-bütünleşme katsayısı 0.28 bulunmuştur. Bu durum, ülkelerin genelinde tasarrufların yatırımların \%28'ini karşıladığını belirtmektedir. F-H hipotezine göre; sermaye liberalizasyonunun olduğu ülkelerde yatırım-tasarruf ilişkisi zayıf olacaktır. Bu çerçevede değerlendirildiği zaman hipotezin ülkelerin geneli için geçerli olduğu ifade edilebilir. Ülkeler ayrı ayrı incelendiğinde ise incelenen 16 ülkeden 11 'inde eşbütünleşme katsayısı istatistiki olarak yorumlanabilir düzeydedir. Tasarrufların yatııımları karşılama düzeyinin en fazla olduğu ülkeler sırasıyla; Türkiye, Belçika, İrlanda, Fransa, İtalya, Danimarka, İsveç, Portekiz, Finlandiya, İngiltere ve Yunanistan'dır. Yurt içi tasarrufların yatırımları karşılama oranının; özellikle sermaye hesabı liberalizasyonunu diğer ülkelere göre daha sonra gerçekleştiren Türkiye'de en yüksek çıkması hipotezi destekler niteliktedir.

Sonuç olarak, ülkelerin sürdürülebilir büyümeyi sağlamasında yatırım ve tasarruf önemli iki makroekonomik değişkendir. 1970'lerden itibaren küreselleşme süreci sermaye hareketleri üzerindeki engellerin kaldırılması ile birlikte yurt içi yatırımlar ve tasarruflar bu süreçten etkilenmiş ve yatırım-tasarruf ilişkisi birçok çalışmaya konu olmuştur. Uluslararası sermayenin istikrarsız olabileceği ve kısa dönemli kar amaçlı portföy yatırımı ağırlıklı olduğu dikkate alınırsa, kısa vadeli sermaye hareketlerinin kontrol altına alınması 
ve sürdürülebilir büyüme için öncelikle yurt içi tasarrufların arttırılması önemlidir. Ülkelerin merkez bankaları ve ekonomiye yön veren karar vericilerin yurt içi tasarrufları arttırıcı tedbirler almaları gerekmektedir. Türkiye'de tasarrufu arttırmak amacıyla bireysel emeklilik sisteminin \%25 devlet katkısılla desteklenmesi bu çerçevede değerlendirilebilir. Ayrıca, özellikle kullanılan kredilerin tüketime dayalı olması sebebiyle kredi hacmini kontrol altında tutmaları gerektiği düşünülmektedir. Nitekim 2008 küresel ekonomik krizin kontrolsüz dağıtılan konut kredilerinden kaynaklanması, analiz sonuçlarını doğrular niteliktedir.

F-H hipotezine göre; sermaye hareketleri üzerinde kısıtların olmadığı durumda yurt içi yatırımlar dış fonlarla finanse edilecek, yurt içi yatırım-tasarruf ilişkisi olmayacak ya da düşük düzeyde olacaktır, aksi takdir- de ilişki güçlü olacaktır. Fakat ülkeye gelen sermaye her zaman yatırım amaçlı gelmeyecek ve büyümeyi desteklemeyecektir. Kısa vadeli spekülatif sermaye hareketlerinin krizlere bile neden olabileceği sıklıkla vurgulanmaktadır. Ülkede sermaye hareketleri üzerinde kısıtlar olmasa bile, ülkenin ekonomik-politik ve siyasi konumu sebebiyle sermaye girişleri olmayabilir ya da kısa vadeli kar amaçlı olabilir. Ayrıca yatırım-tasarruf iliş̧kisinin ve bütçe dengesinin cari açığın belirleyicisi olduğu düşünülürse tasarrufların arttırılması, yatırımların öncelikle yurt içi kaynaklarla finanse edilmesi ve gelen dış sermayenin kalıcı yatırımlara teşvik edilmesi ülke ekonomilerinin istikrarlı ve sürdürülebilir büyümeyi başarabilmesini kolaylaştıracaktır. 


\section{SON NOTLAR}

${ }^{1}$ Solow (1956) Neo-klasik büyüme modelinde azalan verimler kanununa göre model durağan hale geldiğinde büyümeyi etkileyen temel unsur teknolojik değişimler ve nüfus artışıdır. Tasarruf oranı ile durağan olan sermayeişgücü ve kişi başı gelir doğru orantılıdır. Tasarruf oranı yüksek olan ülkeler diğerlerine göre durağan halde sermaye yoğun ve zengin olacaktır (Kar ve Taban, 2003).

${ }^{2}$ Kısa dönem uyarlama hızı katsayısının bire bölümü, uzun dönem dengesine kaç dönem içinde yakınsama olacağını verir (Tarı, 2008). Çalışmada $1 / 0,256 \cong 4$ dönem içinde yakınsama gerçekleşecektir.

${ }^{3} \mathrm{Bu}$ çalışma 19-21 Haziran 2013 tarihleri arasında Anadolu Üniversitesinde düzenlenen uluslararası "Anadolu International Conference in Economics - EconAnadolu 2013" kongresinde sunulan bildirinin genişletilmiş ve gözden geçirilmiş halidir. Kodlar için İTÜ Ekonomi bölümünden Doç. Dr. Bülent GÜLOĞLU ve Pamukkale Üniversitesinden Doç. Dr. Şaban NAZLIOĞLU'na teşekkür ediyorum.

\section{KAYNAKLAR}

Abbott, A. ve De Vita, V. (2003) "Another Piece in the Feldstein-Horioka Puzzle" Scottish Journal of Political Economy, 25:69-89.

Altıntaş, H. ve Taban, S. (2011) “Twin Deficit Problem and Feldstein-Horioka Hypothesis in Turkey: ARDL Approach and Investigation of Causality" International Research Journal of Finance and Economics, 74: 30-45.

Ang, J.B. (2007) "Are Saving and Investment Cointegrated? The Case of Malaysia (1965-2003)" Applied Economics, 39-17:2167-2174.

Apergis, N. ve Tsoulfidis, L. (1997) "The Relationship Between Saving and Finance: Theory and Evidence From EU Countries" Research in Economics, 51:333-358.

Bai, J. ve Perron, P. (1998) "Estimating and Testing Linear Models with Multiple Structural Changes" Econometrica, 66(1):47-78.

Bai, J. ve Ng, S. (2004) "A Panic Attack on Unit Roots and Cointegration” Econometrica, 72(4):1127-1178.

Basher, S.A. ve Westerlund, J. (2009) "Panel Cointegration and the Monetary Exchange Rate Model" Economic Modelling, 26:506-513.

Baxter, M. ve Crucini, M.J. (1993) "Explaining Saving-Investment Correlations" The American Economic Review, 83(3):416-436.

Beyaert, A. ve Camacho, M. (2008) “TAR Panel Unit Root Tests and Real Convergence: An Application to the EU Enlargement Process" Review of Development Economics, 12(3):668-681.

Bhagwati, J. (1998) "The Capital Myth: The Difference between Trade in Widgets and Trade in Dollars" Foreign Afairs, 77:7-12.

Blanchard, O. ve Giavazzi, F. (2002) "Current Account Deficits in The Euro Area: The End of The Feldstein_Horioka Puzzle?" Brookings Papers on Economic Activity, 2:147-209.
Bolatoğlu, N. (2005) “Türkiye'de Yurt içi Yatırım ve Yurt içi Tasarruf Oranları Arasındaki İlişki” Ekonomik Yaklaşım, 16(56):19-32.

Boratav, K. (2009) Küreselleşme, Kriz ve Türkiye'de Neoliberal Dönüşüm İstanbul Bilgi Üniversitesi Yayınları, No:234.

Brezis, E.S. (1995) "Foreign Capital Flows in the Century of Britian's Industrial Revolution: New Estimates, Controlled Conjectures" The Economic History Review, 48(1):46-67.

Breusch, T.S. ve Pagan, A.R. (1980) “The Lagrange Multiplier Test and Its Applications to Modelspecification Tests in Econometrics" Review of Economic Studies, 47(1):239-53.

Breitung, J. (2005) "A Parametric Approach to the Estimation of Cointegrating Vectors in Panel Data" Econometric Reviews, 24(2):151-173.

Breuer, B., Mcnown, R. ve Wallace, M. (2002) "Series-Specific Unit Root Test with Panel Data” Oxford Bulletin of Economics and Statistics, 64(5):527-546.

Caprio, G.A. ve Howard, D.H. (1984) “Domestic Saving, Current Accounts, and International Capital Mobility" International Finance Discussion Paper, No:244.

Carrion-I-Silvestre, J.L., Barrio-Castro, T.D. ve Lopez-Bazo, E. (2005) "Breaking the Panels: An Application to the GDP Per Capita” Econometrics Journal, 8:159-175.

Charemza, W.W. ve Deadman, D.F. (1997). New Directions in Econometric Practice: General to Specific Modelling, Cointegration and Vector Autoregression, $2^{\text {nd }}$ Edition, UK Chelthenham, Edward Elgar Publishing.

Choi, I. (2001) "Unit Roots Tests for Panel Data" Journal of International Money and Finance, 20:229-272.

Coakley, J., Kulasi, F. ve Smith, R. (1996) "Current Account Solvency and The Feldstein-Horioka Puzzle" Economic Journal, 106:620-27. 
Coakley, J. ve Kulasi, F. (1997) "Cointegration of Long Span Saving and Investment" Economics Letters, 54:1-6.

Eberhardt, M. ve Bond, S. (2009) Cross-section Dependence in Nonstationary Panel Models: A Novel Estimator, Munich Personal RePEc Archive Paper, No: 17692.

Erden, L. (2005) "Structural Adjustment and Domestic Private Saving and Investment Interaction in Turkey: A Cointegration Analysis" Yönetim ve Ekonomi, 12(1):95103.

Esen, E., Yıldırım, S. ve Kostakoğlu, F. (2012) "Feldstein-Horioka Hipotezinin Türkiye Ekonomisi için S1nanması: ARDL Modeli Uygulaması" Eskişehir Osmangazi Üniversitesi İktisadi ve İdari Bilimler Fakültesi Dergisi, $7(1): 251-267$.

Feldstein, M. ve Horioka, C. (1980) “Domestic Saving and International Capital Flows" Economic Journal, 90:314-329.

Feldstein, M. (1983) "Domestic Saving and International Capital Movements in the Long Run and the Short Run” European Economic Review, 21:331-353.

Feldstein, M. ve Bachetta, P. (1991) "National Saving and Economic Performance" Shoven, et al(eds.) National Saving And International Investment, USA University of Chicago Press.

French, K.R. ve Poterba, J.M. (1991) "Investor Diversification and International Equity Markets" The American Economic Review, 81(2):222-226.

Georgopoulos, G. ve Hejazi, W. (2005) "FeldsteinHorioka Meets A Time Trend" Economics Letters, 86:353357.

Hadri, K. (2000) "Testing for Stationarity in Heterogenous Panels” Econometrics Journal, 3: 148-161.

Helliwell, J. (2004) "Demographic Change And International Factor Mobility" NBER Working Paper Series, No: 10945 .

Hussein, K.A. (1998) "International Capital Mobility in OECD Countries: The Feldstein-Horioka 'Puzzle' Revisited” Economics Letters, 59:237-242.

Husted, S. (1992) “The Emerging U.S. Current Account Deficit in the 1980s: A Cointegration Analysis" The Review of Economics \& Statics, 159-166.

Im, K., Pesaran, H. ve Shin, Y. (2003) “Testing for Unit Roots in Heterogenous Panels" Journal of Econometrics, 115(1):53-74.

Jansen, W. J. (1998) "Interpreting saving-investment correlations" Open Economies Review, 9: 205-217.
Kar, M. ve Taban, S. (2012) "Kamu Harcama Çeşitlerinin Ekonomik Büyümeye Etkisi” Ankara Üniversitesi SBF Dergisi, 58(3):145-168.

Ketenci, N. (2012) "The Feldstein-Horioka Puzzle And Structural Breaks: Evidence from EU Members" Economic Modelling, 29(2012):262-270.

Kim, S.H. (2001) "The Saving-Investment Correlation Puzzle is Still A Puzzle" Journal of International Money and Finance, 20:1017-1034.

Kollias, C., Mylonidis, N. ve Paleologou, S.M. (2008) "The Feldstein-Horioka Puzzle Across EU Members: Evidence From The ARDL Bounds Approach And Panel Data" International Review of Economics and Finance 17:380-387.

Levin, A., Lin, C.F. ve Chu, C.S.J. (2002) "Unit Root Tests in Panel Data: Asymptotic and Finite Sample Properties" Journal of Econometrics, 108:1-24.

Liu, J., Wu, S. ve Zidek, J.V. (1997) “On Segmented Multivariate Regressions” Statistica Sinica, 7:497-525.

Maddala, G.S. ve Wu, S. (1999) "A Comparative Study of Unit Root Tests with Panel Data and a New Simple Test" Oxford Bulletin of Economics and Statistics 61:631-652.

Mamingi, N. (1993) "Savings Investment Correlations and Capital Mobility in Developing Countries" The World Bank Policy Research Working Paper Series, No:1211.

Mangır, F. ve Ertuğrul, H.M. (2012) "Sermaye Hareketliliği, Tasarruf ve Yatırım Ilişkisi: Türkiye Örneği” Íktisat İsletme Finans, 27(317):61-87.

Mercan, M. ve Göçer, İ. (2012) “Zamanlararası Dış Denge Ve Optimizasyon Yaklaşımları Çerçevesinde Türkiye'de Cari Açığın Sürdürülebilirliği” Akdeniz Üniversitesi İktisadi ve İdari Bilimler Fakültesi Dergisi, 11(24):2012.

Murphy, R.G. (1984) "Capital Mobility and The Relationship Between Saving and Investment in OECD Countries" Journal of International Money and Finance, 3:327-342.

Narayan, P.K. (2005) "The Saving and Investment Nexus for China: Evidence from Cointegration Tests" Applied Economics, 37(17):1979-1990.

Obstfeld, M. ve Rogoff, K. (1996) Foundations of International Macroeconomics. USA, The MIT Press.

Penati, A.ve Dooley, M.P. (1984) "Current Account Imbalances and Capital Formation in Industrial Countries: 1948-1981” IMF Staff Papers, 31:1-24.

Pesaran, M.H. (2004) "General Diagnostic Tests for Cross Section Dependence in Panels" Cambridge Working Papers in Economics, No:435. 
Pesaran, M.H. (2006) "Estimation and Inference in Large Heterogeneous Panels with a Multifactor Error Structure" Econometrica, 74(4):967-1012.

Pesaran, M.H., Ullah, A. ve Yamagata, T. (2008) "A Bias-Adjusted LM Test of Error Cross-Section Independence" Econometrics Journal, 11(1):105-127.

Pesaran, M.H. ve Yamagata, T. (2008) "Testing Slope Homogeneity in Large Panels" Journal of Econometrics, 142(1):50-93.

Rocha, F. ve Zerbini, M.B. (2003) "Using a Panel Structure to Discuss the Feldstein-Horioka Puzzle in Developing Countries" 1-27.

Rodrik, D. (1998) "Who Needs Capital Account Convertibility?" Princeton Essays in International Finance, 207:55-65.

Sachs, J. (1981) "The Current Account and Macroeconomic Adjustment in The 1970's" Brookings Papers on Economic Activity, 1:201-268.

Sinha, D. ve Sinha, T. (1998) "An Exploration of the Long-Run Relationship Between Saving and Investment in the Developing Economies: A Tale of Latin American Countries" Journal of Post-Keynesian Economics, 20(3):435-443.
Stiglitz, E.J. (2002). Globalization and Its Discontents. New York, W.W.Norton Publication.

Swamy, P.A.V.B. (1970) "Efficient Inference in a Random Coefficient Regression Model" Econometrica, 38(2):311-323.

Tar1, R. (2008) Ekonometri, 8. Baskı, İstanbul, Avc1 Ofset.

Taylor, M. ve Sarno, L. (1998) "The Behaviour of Real Exchange Rates during the Post-Bretton Woods Period" Journal of International Economics, 46:281-312.

TCMB (2002) Küreselleşmenin Türkiye Ekonomisine Etkileri, Ankara,Türkiye Cumhuriyet Merkez Bankası Yayınları.

Tesar, L. (1991) "Savings, Investment and International Capital Flows" Journal of International Economics, 31:29-42.

Tesar, L. ve Werner, I.M. (1995) "Home Bias and High Turnover" Journal of International Money and Finance, 14(4):467-492.

Tobin, J. (1983) "Domestic Saving and International Capital Movements in The Long Run and The Short Run' by M. Feldstein” European Economic Review, 21(12):153-156 
